\title{
ANATOMY AND PATHOLOGY OF THE VITREO-RETINAL INTERFACE
}

\author{
J. SEBAG \\ Huntington Beach, California
}

\section{MORPHOLOGY}

\section{Macroscopic Structure}

\section{Historical Perspective}

Duke-Elder ${ }^{1}$ has stated that the first descriptions of vitreous structure proposed that the vitreous was composed of 'loose and delicate filaments surrounded by fluid'. During the eighteenth and nineteenth centuries there prevailed no less than four different theories of vitreous structure. In 1741, Demours ${ }^{2}$ formulated the 'alveolar theory', wherein he described a multitude of membranes oriented in all possible directions, enclosing compartments or alveoli containing the fluid portion of the vitreous. In $1780, \mathrm{Zinn}^{3}$ proposed that the vitreous is arranged in a concentric, lamellar configuration ('lamellar theory') similar to the layers of an onion. The 'radial sector theory' was first proposed by Hannover ${ }^{4}$ who described a multitude of sectors approximately radially oriented about the central anteroposterior core that contains Cloquet's canal. Hannover likened this structure to the appearance of a cut orange. For many years controversy existed between proponents of the 'lamellar theory' and supporters of the 'radial sector theory'. Smith ${ }^{5}$ and Von Gerlach ${ }^{6}$ attempted to unify the two theories by stating that the peripheral vitreous has concentric lamellae while the central vitreous is organised in 'radial sector' structures.

In 1848 Bowman $^{7}$ introduced the 'fibrillar theory'. Employing microscopy, he described fine fibrils that form bundles with 'nuclear' granules. Blix ${ }^{8}$ proposed that these nuclear granules were actually the intersection sites of fibres coursing in all directions. Retzius ${ }^{9}$ described fibrous structures arising in the peripheral anterior vitreous that assume an undulating pattern similar to a horse's tail in the central vitreous but maintain a concentric configuration at the periphery. Virchow ${ }^{10}$ attempted to unify the 'alveolar'

Correspondence to: J. Sebag, MD, FACS, FCOphth, 11th Floor, Pacifica Tower, 18800 Delaware Street, Huntington Beach, CA 92648, USA. and 'fibrillar' theories by stating that compartments or alveoli are separated by fibrils. The elegant studies of Szent-Gyorgi ${ }^{11}$ in 1917 supported the descriptions of Retzius and introduced the concept that vitreous structure changes with age.

The work of Redslob ${ }^{12}$ and others showed that many of the early studies were flawed by artefacts due to the use of tissue fixatives. Thus, it was anticipated that the use of a slit lamp to examine the vitreous would eliminate this problem. Yet, in vivo slit lamp biomicroscopy spawned an equally varied set of descriptions. Gullstrand ${ }^{13}$ saw membranes, Koeppe ${ }^{14}$ described vertical and horizontal fibres, and Baurmann ${ }^{15}$ saw a grill-like pattern of darker and lighter bands resembling several layers of chain-linked fences. Even the use of post-mortem dark-field microscopy resulted in various interpretations ranging from Goedbloed's ${ }^{16}$ description of fibrillar structures to Friedenwald and Stiehler's ${ }^{17}$ description of concentric sheets and Eisner's ${ }^{18}$ observation of 'membranelles', which he has named tractae. Worst ${ }^{19}$ has also studied dissected preparations and described that the tractae of Eisner constitute the walls of vitreous 'cisterns' and 'bursae'.

\section{Clinical Morphology}

The vitreous of an emmetropic human eye is approximately $16.5 \mathrm{~mm}$ in axial length with a depression anteriorly just behind the lens.(patellar fossa). Various structures and regions within the vitreous are named after the anatomists and histologists who first described them (Fig. 1). The hyaloideocapsular ligament (of Weiger) is the annular region $1-2 \mathrm{~mm}$ in width and $8-9 \mathrm{~mm}$ in diameter where the vitreous is attached to the posterior aspect of the lens. Erggelet's or Berger's space is at the centre. of the hyaloideocapsular ligament. Arising from this space and coursing posteriorly through the central vitreous is Cloquet's canal which is the former site of the hyaloid artery in the primary vitreous. The former lumen of the artery is an area devoid of vitreous collagen fibrils, sur- 


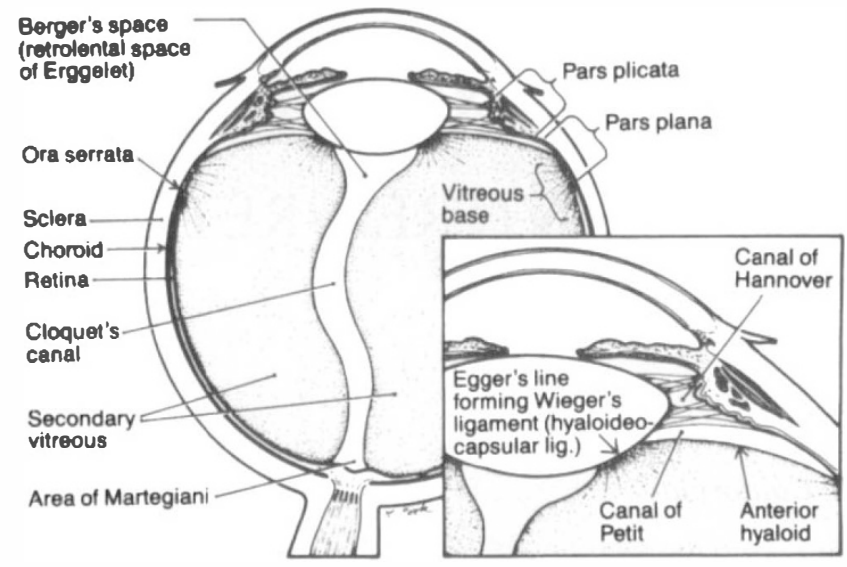

Fig. 1. Schematic diagram of vitreous anatomy. The classical nomenclature uses the names of the anatomists and histologists who originally described the structures. (Reprinted from Schepens $C L$ and Neetens $A(e d s)$ : Vitreous and Vitreoretinal Interface. New York: Springer-Verlag, 1987, p. 20.)

rounded by multi-fenestrated sheaths that were previously the basal laminae of the hyaloid artery wall. Posteriorly, Cloquet's canal opens into a funnel-shaped region anterior to the optic disc known as the area of Martegiani.
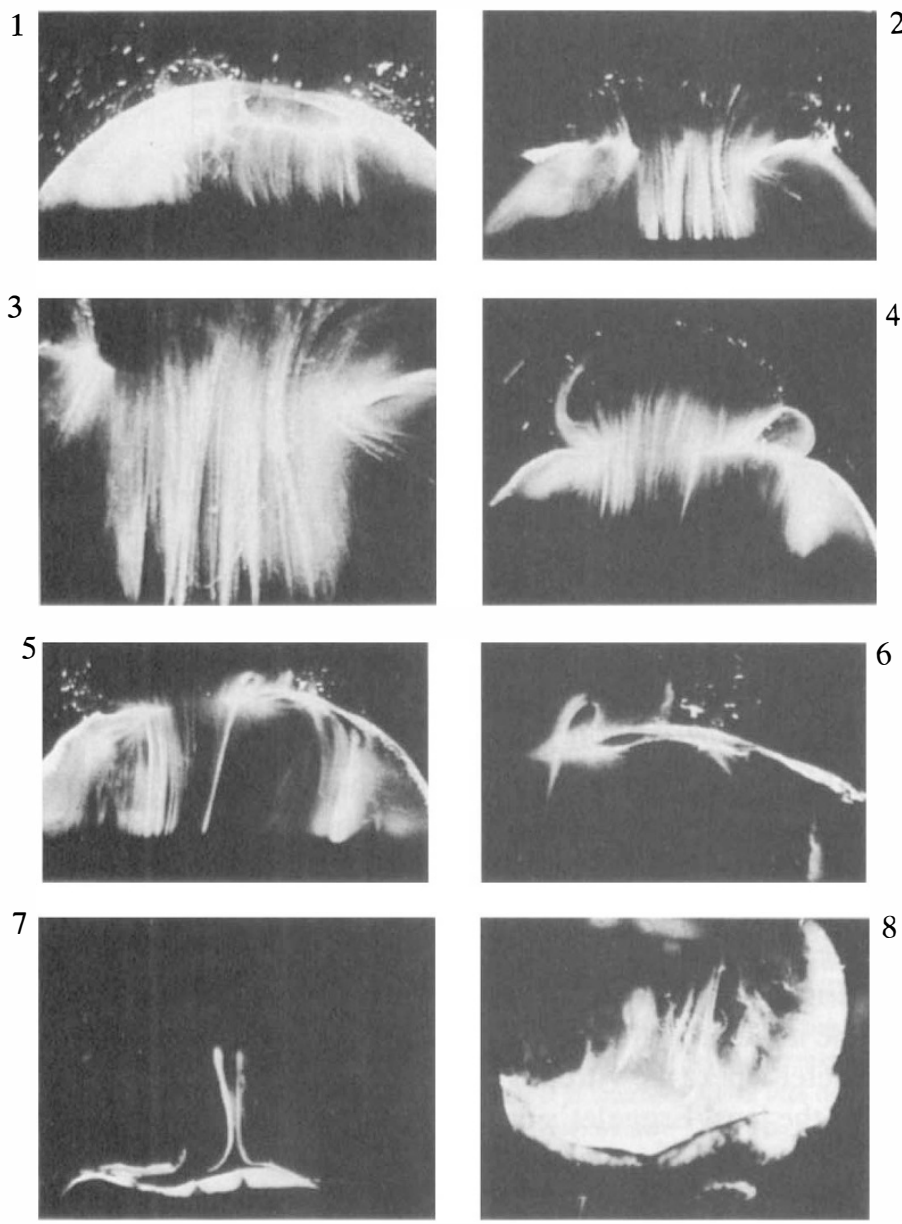

Fig. 2. Human vitreous morphology. Human vitreous structure was visualised by dark-field slit illumination. All photographs are oriented with the anterior segment below and the
Recent studies ${ }^{20-23}$ have used fresh autopsy eyes from which the sclera, choroid and retina were dissected away to study human vitreous structure. Within the adult human vitreous there are fine, parallel fibres coursing in an anteroposterior direction as shown in Figs. 2.1 and 2.2. The fibres arise from the vitreous base (Fig. 2.8) where they insert anterior and posterior to the ora serrata. As the peripheral fibres course posteriorly they are circumferential with the vitreous cortex, while central fibres 'undulate' in a configuration parallel with Cloquet's canal. The fibres are continuous and do not branch. Posteriorly, these fibres insert into the vitreous cortex (Figs. 2.5 and 2.6). Ultrastructural studies ${ }^{23}$ have demonstrated that collagen fibrils are the only microscopic structures that could correspond to these fibres. These studies also detected the presence of bundles of packed, parallel collagen fibrils.

There are changes that occur in these fibrous structures throughout life..$^{20.24}$ These are probably the result of agerelated biochemical alterations in the composition and organisation of the molecular components that simultaneously result in vitreous liquefaction and fibre formation. $^{24} \mathrm{~A}$ recent report ${ }^{25}$ described the presence of a 'posterior vitreous pocket' which the authors interpreted as representing an anatomical entity. However, over $95 \%$

2 posterior pole above. Photographs are sequential, beginning in the upper left-hand corner and moving left to right.

(1) Posterior vitreous in the left eye of a 52-year-old male. The vitreous is enclosed by the vitreous cortex. There is a hole in the prepapillary (small, to the left) vitreous cortex. Vitreous fibres are oriented towards the macular region where vitreous extends posteriorly through the premacular vitreous cortex.

(2) Posterior vitreous in a 57-year-old male. A large bundle of prominent fibres is seen coursing anteroposteriorly and entering the retrocortical space via the premacular vitreous cortex.

(3) Same as Fig. 2.2 at higher magnification.

(4) Posterior vitreous in the right eye of a 53-year-old female. There is posterior extrusion of vitreous out the prepapillary hole (to the right) and premacular (large extrusion to the left) vitreous cortex. Fibres course anteroposteriorly out into the retrohyaloid space.

(5) Horizontal optical section of the same specimen as Fig. 2.4 at a different level. A large fibre courses posteriorly from the central vitreous and inserts into the vitreous cortex at the rim of the premacular hole in the vitreous cortex.

(6) Same view as Fig. 2.5 at higher magnification. The large fibre has a curvilinear appearance because of traction by the vitreous extruding into the retrocortical space. However, because of its attachment to the posterior vitreous cortex the fibre arcs back to its point of insertion.

(7) Anterior and central vitreous in a 33-year-old woman. Cloquet's canal is seen forming the retrolental space of Berger.

(8) Anterior and peripheral vitreous in a 57-year-old male. The specimen is tilted forwards to enable visualisation of the posterior aspect of the lens and the peripheral anterior vitreous. Behind and to the right of the lens there are fibres coursing anteroposteriorly that insert into the vitreous base. These fibres 'splay out' to insert anterior and posterior to the ora serrata.

Figs. 2.1, 2.5 and 2.6 are reprinted with permission from Sebag $J$ and Balazs EA: Pathogenesis of cystoid macular edema: an anatomic consideration of vitreoretinal adhesions. Surv Ophthalmol 1984, 28 (Suppl): 493-8. Figs 2.2. and 2.3 are reprinted with permission from Sebag J, Balazs EA: Morphology and ultrastructure of human vitreous fibers. Invest Ophthalmol Vis Sci 1989, 30: 187-91. 
of the eyes examined in this study were from individuals aged 65 years or older. Thus, these findings probably represent the result of age-related vitreous liquefaction in the precortical posterior vitreous. ${ }^{20,24}$

\section{Microscopic Structure}

Gartner ${ }^{26}$ has found that in humans the diameters of collagen fibrils in the vitreous base range from 10.8 to $12.4 \mathrm{~nm}$, with a major period of cross-striations of 50 $54 \mathrm{~nm}$. Hogan ${ }^{27}$ demonstrated that just posterior to the ora serrata, heavy bundles of vitreous fibrils attach to the basal laminae of retinal glial cells. Studies by Gloor and Daicker $^{28}$ showed that cords of vitreous collagen insert into gaps between the neuroglia of the peripheral retina. They likened this structure to Velcro and proposed that this would explain the strong vitreo-retinal adhesion at this site. In the anterior vitreous base fibrils interdigitate with a reticular complex of fibrillar basement membrane material between the crevices of the non-pigmented ciliary epithelium. ${ }^{29}$ The vitreous base also contains intact cells that are fibroblast-like anterior to the ora serrata and macrophage-like posteriorly. ${ }^{29}$

\section{Posterior Vitreous Cortex}

The vitreous cortex is defined as the peripheral 'shell' of the vitreous that courses forwards and inwards from the anterior vitreous base to form the anterior vitreous cortex, and posteriorly from the posterior border of the vitreous base to form the posterior vitreous cortex.

The posterior vitreous cortex is $100-110 \mu$ thick $^{30,31}$ and consists of densely packed collagen fibrils (Fig. 3). ${ }^{32}$ There is no vitreous cortex over the optic disc (Figs. 2.1 and 2.4) and the cortex is thin over the macula due to rarefaction of the collagen fibrils. ${ }^{33}$ The prepapillary hole in the vitreous cortex can sometimes be visualised clinically when the posterior vitreous is detached from the retina. If peripapillary glial tissue is torn away during posterior vitreous detachment and remains attached to the vitreous cortex about the prepapillary hole it is referred to as Vogt's or Weiss's ring. Vitreous can extrude through the prepapillary hole in the vitreous cortex (Fig. 2.1) but does so to a much lesser extent than through the premacular vitreous cortex (Figs. 2.2 and 2.4 and Fig. 4). Jaffe ${ }^{34}$ has described how vitreous can extrude into the retrohyaloid space created following posterior vitreous detachment and has proposed that persistent attachment to the macula can produce traction and certain forms of maculopathy (see below).

Hyalocytes. Reeser and Aaberg ${ }^{35}$ consider the vitreous cortex to be the metabolic centre of the vitreous because of the presence of hyalocytes (Figs. 4 and 5). These cells were first described in 1845 by Hannover. ${ }^{36}$ Schwalbe $^{37}$ placed these cells into the group of Wanderzellen (wandering cells, i.e. leucocytes or macrophages) on the basis of their morphology, distribution and behaviour. Balazs modified Schwalbe's term Subhyaloidalezellen ${ }^{38}$ and named these cells 'hyalocytes'.

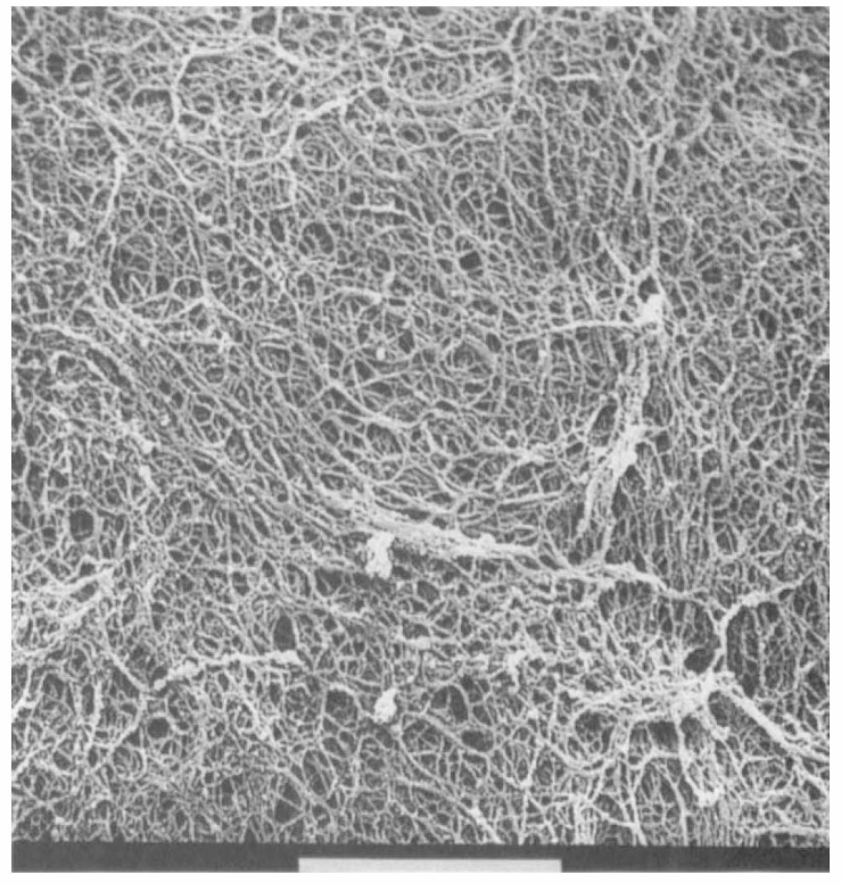

Fig. 3. Scanning electron micrograph of posterior aspect of posterior vitreous cortex from an 11 -year-old. The retina has been dissected away. The density of compacted collagen fibrils of the posterior vitreous cortex is slightly exaggerated by dehydration in processing the specimen. White scale bar at bottom of photograph represents $10 \mu \mathrm{m}$.

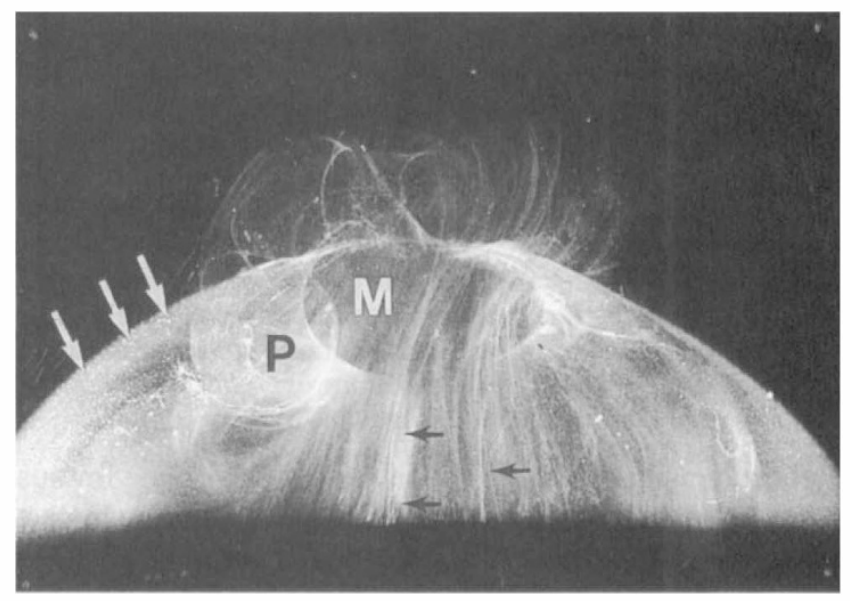

Fig. 4. Dark-field slit microscopy of posterior vitreous in the left eye of a 59-yearsold man. The small hole $(P)$ is the prepapillary hole in the posterior vitreous cortex. Vitreous extrudes posteriorly through the premacular vitreous cortex $(M)$ to a greater extent than through the prepapillary hole. Hyalocytes are embedded in the vitreous cortex (white arrows) and fibres are present in the central vitreous (black arrows). (Reprinted with permission from Sebag J, Balazs EA: Human vitreous fibres and vitroretinal disease. Trans Ophthalmol Soc UK 1985, 104: 123-8.

Hyalocytes are embedded in the vitreous cortex (Figs. 4 and 5) widely spread out in a single layer situated 20$50 \mu \mathrm{m}$ from the internal limiting lamina of the retina posteriorly and the basal lamina of the ciliary epithelium at the pars plana and vitreous base. Quantitative studies of cell density in the bovine ${ }^{40}$ and rabbit ${ }^{41}$ vitreous found the 


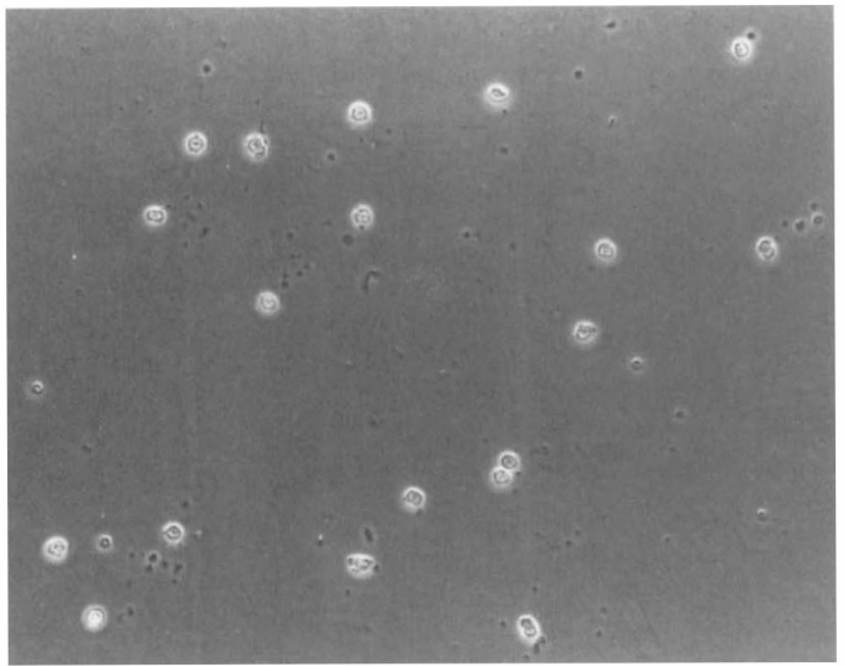

Fig. 5. Hyalocytes. (a) Phase-contrast microscopy of vitreous cortex from an 11-year-old girl who died of an anaphylactic reaction to a bee sting (courtesy of the New England Eye Bank). No fixatives or stains were employed. Mononuclear cells are spread widely apart in a single layer within the vitreous cortex. (b) Transmission electron micrograph of human hyalocyte demonstrates dense granules (arrows), rough endoplasmic reticulum, vacuoles $(V)$, ribosomes, suface microvilli (Mi), and adjacent cortical collagen fibrils $(C)$. $M$, mitochondria; $N$, nucleus. $(\times 11670)$. (Reprinted with permission from Sebag J: The Vitreous: Structure, Function, and Pathobiology. New York: Springer-Verlag, 1989, p. 49; photomicrograph courtesy of J. Craft and D. Albert, Cogan Laboratory of Ophthalmic Pathology, Harvard Medical School, Boston, Mass).

highest density of hyalocytes in the region of the vitreous base, followed next by the posterior pole, with the lowest density at the equator. Hyalocytes are oval or spindleshaped, $10-15 \mu \mathrm{m}$ in diameter, and contain a lobulated nucleus, a well-developed Golgi complex, smooth and rough endoplasmic reticula, and many large PAS-positive lysosomal granules and phagosomes. ${ }^{42,43}$ Hogan et al.$^{44}$ described that the posterior hyalocytes are flattened and spindle-shaped, whereas anterior hyalocytes are larger, rounder and at times star-shaped. Saga et al. ${ }^{45}$ have described that different ultrastructural features can be present in different individual cells of the hyalocyte population in an eye. Whether this relates to different origins for the different cells or different states of cell metabolism or activity is not clear. The metabolic activities ascribed to hyalocytes include hyaluronan synthesis ${ }^{39,46.47}$ glycoprotein production, ${ }^{48}$ collagen synthesis, ${ }^{48,49}$ and the release of certain enzymes. ${ }^{50}$

Phagocytic capacity of hyalocytes has been described

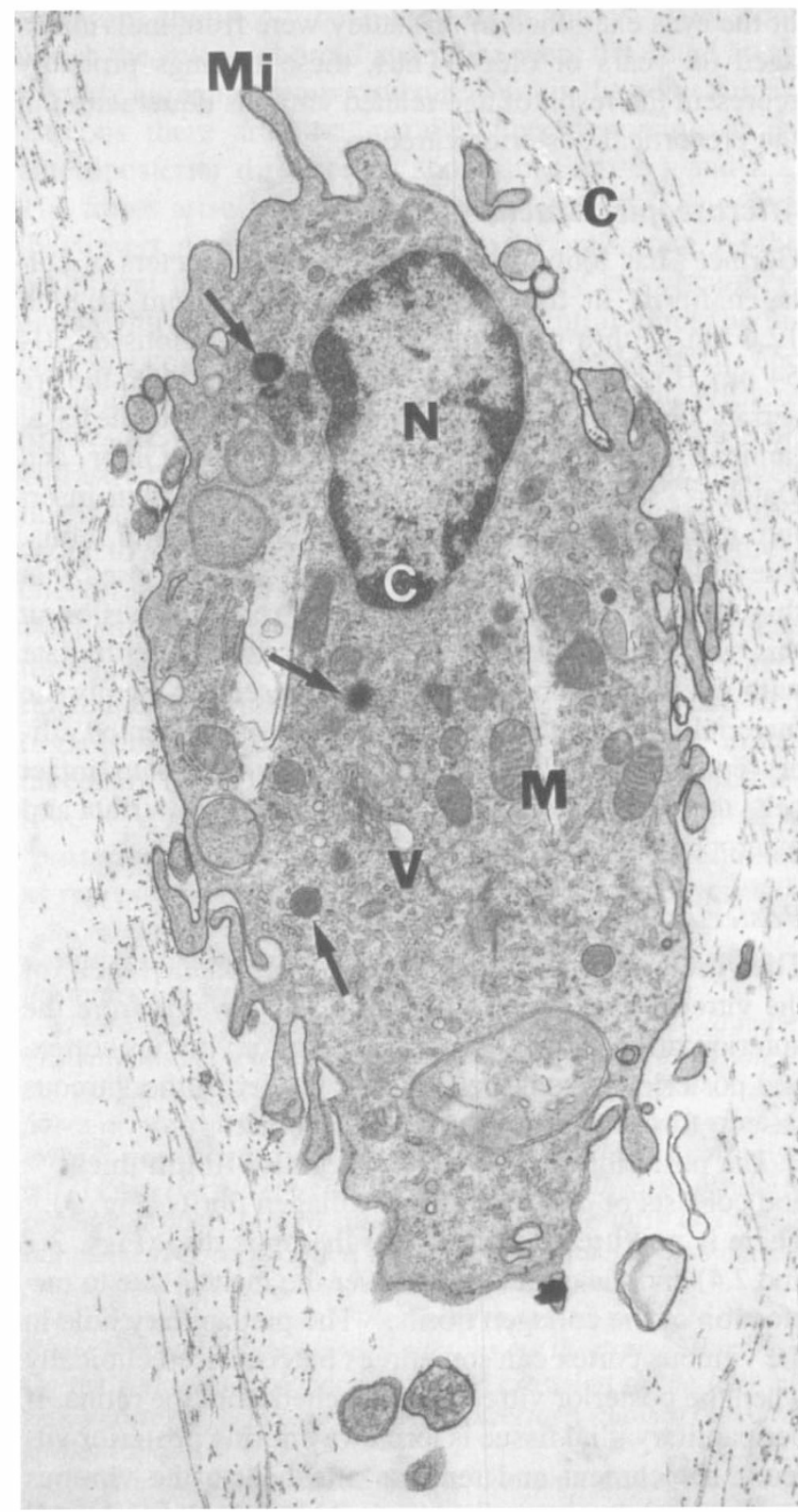

in vivo $o^{51}$ and demonstrated in vitro. ${ }^{52-54}$ This activity is consistent with the presence of pinocytic vesicles and phagosomes and the presence of surface receptors that bind $\mathrm{IgG}$ and complement. ${ }^{54}$ Interestingly, hyaluronan may have a regulatory effect upon hyalocyte phagocytic activity. ${ }^{55,56}$

Fibroblasts. There is a second population of cells in the vitreous cortex which in some cases may be mistaken for hyalocytes. Investigations $\mathrm{s}^{57.58}$ have determined that fibroblasts are present. These cells constitute less than $10 \%$ of the total vitreous cell population and are localised within the vitreous base and adjacent to the optic disc. Studies ${ }^{58}$ have demonstrated that they synthesise glycosaminoglycans in vitro. It may be, however, that in vivo these cells are primarily involved in collagen synthesis, especially in pathological situations. The argument for a role in normal vitreous collagen synthesis is mostly by analogy to studies of fibrillogenesis in tendon, where investigations ${ }^{59}$ have 


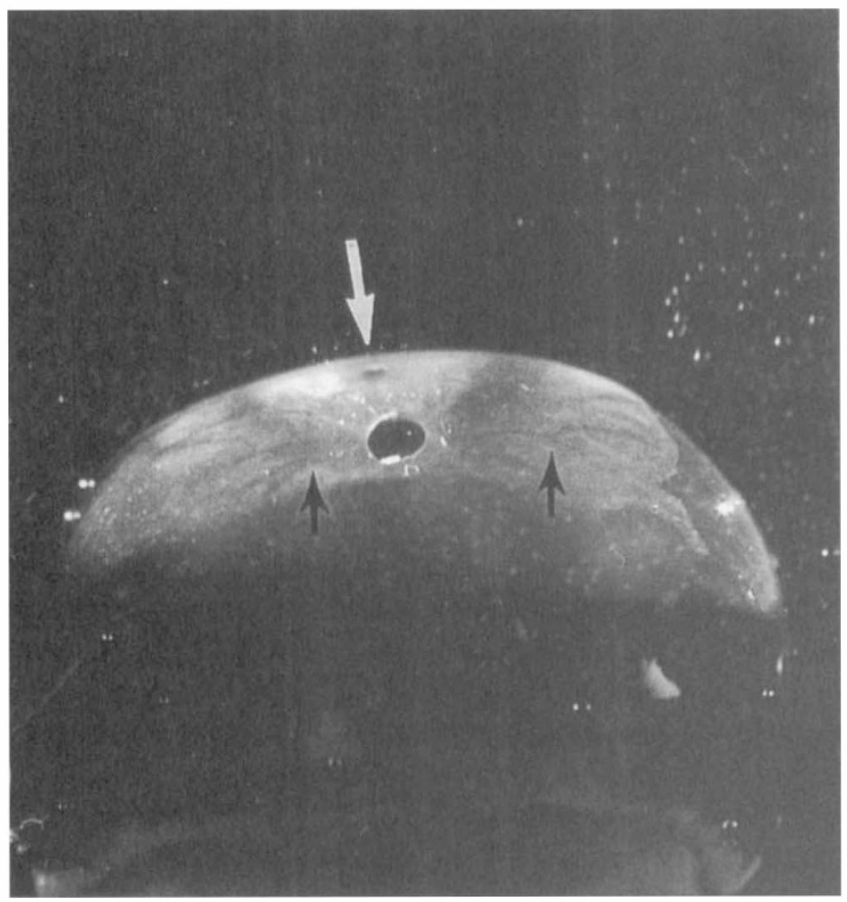

a

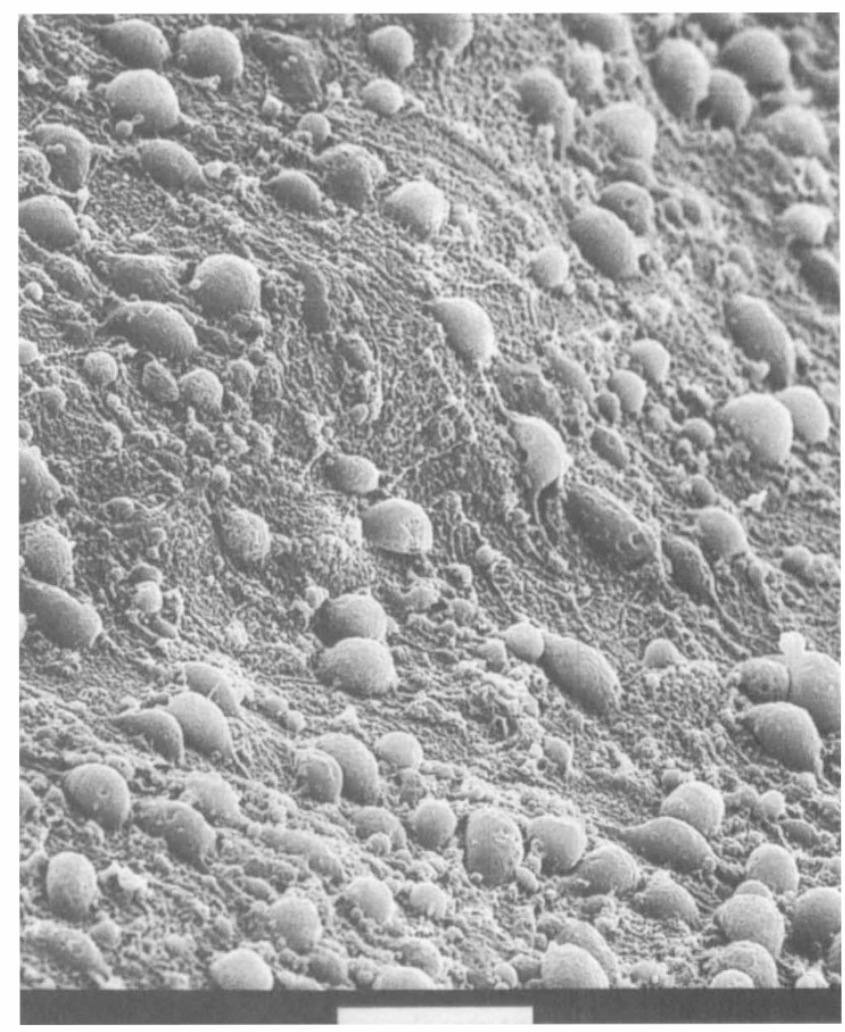

b

Fig. 6. Vitreo-retinal interface. Posterior vitreous in a 14year-old boy. Dissection of the retina off the vitreous resulted in cleavage between the vitreous cortex and the internal limiting lamina (ILL) peripherally. However, posteriorly there was adherent tissue on the vitreous cortex.

(a) Dark-field slit microscopy demonstrates that the tissue adherent to the posterior vitreous has a hole in the region of the optic disc, linear branching patterns (black arrows) arising from this hole (suggestive of retinal vessel 'imprints'), and a focal 'imprint' temporal to the hole (white arrow) corresponding to the fovea.

(b) Scanning electron micrograph of the posterior aspect of the specimen shown in Fig. 6(a), demonstrating multiple protuberances on the posterior surface of the tissue adherent to the posterior vitreous. White scale bar represents $10 \mu \mathrm{m}$.

(c) Transmission electron micrograph of specimen shown in Fig. $6(a)$ and $(b)$ demonstrating that the tissue adherent to the posterior vitreous cortex is the ILL of the retina (open arrows). The protuberances seen on scanning electron microscopy are the inner processes of Müller cells $(M)$ that tore away from the neural retina and remained attached to the ILL. C, collagen fibrils of vitreous cortex artefactually separated from ILL during tissue processing for electron microscopy.

In $40 \%$ of specimens obtained from individuals younger than 20 years, adherence of the ILL to the posterior but not the equatiorial vitreous cortex was stronger than the Müller cells themselves, resulting in these findings. This sheet-like adhesion encompasses the macula and peripapillary region and suggests that strong adherence of vitreous to the posterior pole is not focal but diffuse and results from extracellular matrix components between the type II collagen of the vitreous cortex and the type IV collagen of the ILL. (Reprinted with permission from Sebag J: Age-related differences in the human vitreoretinal interface. Arch Ophthalmol 1991, 109: 966-71. 
found that secreted collagen molecules are assembled into fibrils within invaginations of secreting fibroblasts. The locations of fibroblasts in the anterior peripheral vitreous (vitreous base and near the ciliary processes) and posterior vitreous may explain how vitreous fibres become continuous structures spanning the distance between these locations.

Balazs et $a l .{ }^{57}$ have found that near the pars plana, vitreous fibroblasts decrease in number with age. Gartner ${ }^{26}$ has suggested that changes in these cells are responsible for ageing changes in the collagen network of the vitreous base.

\section{Vitreo-retinal Interface}

The vitreous is situated adjacent to the retina posteriorly and behind the ciliary body and lens anteriorly. At all these sites the interface with neighbouring tissues consists of a complex formed by the vitreous cortex and the basal laminae of the adjacent cells. These basal laminae are firmly attached to their cells ${ }^{40}$ and vitreous cortex collagen fibrils are purported to insert into the basal laminae. ${ }^{60,61}$ However, there are studies ${ }^{44,62}$ which show that the collagen fibrils of the vitreous cortex actually run parallel to the internal limiting lamina (ILL) of the retina. The ILL is essentially the basement membrane of retinal Müller cells. Immediately adjacent to the Müller cell is a lamina rara that is $0.03-0.06 \mu \mathrm{m}$ thick and demonstrates no species variations nor changes with topography or age. The lamina densa is thinnest at the fovea $(0.01-0.02 \mu \mathrm{m})$ and disc $(0.07-0.1 \mu \mathrm{m})$. It is thicker elsewhere in the posterior pole $(0.5-3.2 \mu \mathrm{m})$ than at the equator or vitreous base. ${ }^{62-65}$ The lamina rara externa is the layer that is contiguous with the vitreous cortex. The anterior surface of the ILL (vitreous side) is normally smooth while the posterior aspect is irregular, filling the spaces created by the irregular surface of the subjacent retinal glial cells. ${ }^{63}$ This feature is most marked at the posterior pole, while in the periphery both the anterior and posterior aspects of the ILL are straight. The significance, if any, of this topographic variation is not known.

The basal laminae about the vitreous are composed of type IV collagen closely associated with glycoproteins. ${ }^{66}$ Laminin has been found in the ILL of the monkey retina but not the rabbit. ${ }^{67}$ Jerdan et al. ${ }^{68}$ employed immunofluorescent techniques to study the human ILL and found laminin, fibronectin, proteoglycan and, curiously, type I collagen. The presence of type IV collagen became apparent after pepsin digestion. Other studies ${ }^{69}$ failed to show fibronectin in the normal human vitreo-retinal interface, but demonstrated fibronectin deposition in the presence of abnormal cell migration into this region. Kohno et al ${ }^{70}$ found that in the thickened ILL of older people there was a bilaminar deposition of fibronectin and laminin. Glycoconjugates have also been described in the human ILL that are present in youth but not at older ages, perhaps accounting for decreased vitreo-retinal adhesion with ageing. ${ }^{71}$

At the rim of the optic nerve head the retinal ILL ceases although the basement membrane continues as the inner limiting membrane of Elschnig. ${ }^{72}$ This membrane is $50 \mathrm{~nm}$ thick and is believed to be the basal lamina of the astroglia in the optic nerve head. At the central-most portion of the optic disc the membrane thins to $20 \mathrm{~nm}$, follows the irregularities of the underlying cells of the optic nerve head and is composed only of glycosaminoglycans and no collagen. ${ }^{72}$ This structure is known as the central meniscus of Kuhnt. Balazs ${ }^{73}$ has stated that the Müller cell basal lamina prevents the passage of cells as well as molecules larger than 15-20 nm and proposed that the complex of the posterior vitreous cortex and ILL could act as a molecular sieve. Consequently, the thinness and chemical composition of the central meniscus of Kuhnt and the membrane of Elschnig may account for, among other effects, the frequency with which abnormal cell migration and proliferation arise from or near the optic nerve head.

Zimmerman and Straatsma ${ }^{74}$ described the existence of fine, fibrillar attachments between the posterior vitreous cortex and the ILL and claimed that these result in an extremely intimate union between normal vitreous and retina. The existence of these attachments has not been confirmed and the composition of these fibrillar structures has never been identified. The vitreous is known to be most firmly attached at the vitreous base, the disc and macula, and over retinal blood vessels. In youth, adhesion at the posterior pole is not focal but rather diffuse in a sheet-like configuration encompassing the macula and peripapillary region (Fig. 6). This adhesion weakens with ageing, perhaps related in some way to the thickening of the ILL. The posterior aspect (retinal side) of the ILL demonstrates irregular thickening the farther posteriorly one goes from the ora serrata. ${ }^{66}$ So-called attachment plaques between the Müller cells and the ILL have been described in the basal and equatorial regions of the fundus but not in the posterior pole, except for the fovea. ${ }^{66}$ It has been hypothesised that these develop in response to vitreous traction upon the retina. The thick ILL in the posterior pole dampens the effects of this traction except at the fovea where the ILL is thin. ${ }^{66}$ The thinness of the ILL and the purported presence of attachment plaques at the central macula could explain the predisposition of this region to changes induced by traction.

There is an unusual vitreo-retinal interface overlying retinal blood vessels. Kuwabara and $\operatorname{Cogan}^{75}$ described 'spider-like bodies in the peripheral retina which coiled about blood vessels and connected with the ILL. Pedler ${ }^{76}$ found that the ILL was thin over blood vessels and hypothesised that this was due to the absence of Müller cell inner processes. Wolter ${ }^{77}$ noted the existence of pores in the ILL along blood vessels and found that vitreous strands inserted where the pores were located. Mutlu and Leopold ${ }^{78}$ described that these strands extend through the ILL to branch and surround vessels in what they termed vitreoretinovascular bands. Such structures would explain the strong adhesion between the vitreous and retinal blood vessels. This may provide a shock-absorbing function damping arterial pulsations during the cardiac cycle. However, pathologically this structural arrangement 
could also account for the proliferative and haemorrhagic events associated with vitreous traction upon retinal blood vessels.

\section{PATHOLOGY}

Vitreo-maculopathies can arise from abnormal cell migration and proliferation into or behind the posterior vitreous cortex, or from traction by the vitreous upon the macula. Posterior vitreous detachment (PVD) can play an important role in the pathogenesis of vitreo-maculopathies, as will be discussed below. Indeed some of these disorders may be considered the consequence of anomalous PVD, i.e. that separation of the posterior vitreous cortex from the ILL does not occur cleanly. Rather, portions of retina may remain adherent to the vitreous cortex (Fig. 6) as will be discussed below for some cases of macular hole. In some instances a split in the vitreous cortex during PVD may leave a layer of vitreous attached to the macula while the remaining vitreous detaches forwards. This could underlie certain forms of premacular membrane formation, as described below. A split with cavitation of the vitreous cortex ('vitreoschisis') could be important in macular hole formation, as well as in proliferative diabetic retinopathy.

\section{Tractional Disorders}

\section{Macular Holes}

The precise pathogenesis of macular holes is a matter of controversy and several hypotheses have been presented over the years. Morgan and Schatz ${ }^{79}$ believe that choroidal ischaemia and subsequent vitreous traction during PVD are implicated in the formation of macular holes. Schepens ${ }^{80}$ believes the vitreous exerts anteroposterior traction, followed by contraction and macular hole formation. More recently, Gass ${ }^{81}$ introduced the concept of tangential traction exerted by the posterior vitreous cortex. According to this hypothesis, macular holes develop in stages: during the first stage tangential vitreous traction causes foveolar detachment. Further traction may cause progression to the second stage, a small full-thickness macular hole. This lesion usually enlarges to about one third disc diameter (third stage). If a PVD ensues, this constitutes Gass's fourth stage.

It is likely that macular holes represent the end-stage manifestation of more than one pathophysiological sequence (Table I). According to this new hypothesis, macular holes can be divided into two broad categories. The first category represents operculated macular holes, where anteroposterior traction by vitreous fibres could cause an operculated hole without PVD, or where centripetal (inwards towards the fovea) tangential vitreous traction is exerted by the cortical vitreous in the absence of PVD, during PVD or by a thin premacular membrane. The centripetal contraction could also be due to a combination of forces exerted by the cortical vitreous and by a premacular membrane.

The second category would represent non-operculated macular holes formed by centrifugal (outwards, i.e. away from the fovea) vitreous traction. In this instance there is a split in the vitreous cortex during PVD. A residual layer of cortical vitreous exerts tangential centrifugal traction on the macula creating a macular hole. If the vitreous is still partially attached and a split cortex has formed a cavity ('vitreoschisis'), some of the centrifugal forces may be caused by fluid currents within the schisis cavity. In other instances, a premacular membrane develops in the absence of PVD and creates centrifugal tangential traction. Finally, a partial PVD could occur with residual anteroposterior vitreous traction over the macula creating a hole without an operculum.

In both categories, elevation by vitreous traction and/or liquid vitreous fluid dynamics enlarge the hole and, therefore, theoretically, surgical manipulation with release of this traction could reduce the size of the hole and potentially improve vision. In the case of non-operculated macular holes surgical results could potentially be superior to cases where an operculum is present, because there is less loss of tissue.

Established Macular Holes. Idiopathic senile macular holes afflict individuals in their sixth or seventh decade of life and usually result in legal blindness. Approximately two thirds of the patients are women and the disease is usually unilateral. Funduscopy reveals a central defect in the macula measuring approximately one third of a disc diameter. The hole is often surrounded by a cuff of subretinal fluid and biomicroscopy will sometimes reveal an operculum located in the vitreous cavity anterior to the hole. $^{82}$

The natural history of established macular hole disease is well defined, with most eyes progressing towards legal blindness. Visual loss is thought to be secondary to tissue loss, tissue degeneration, cystic retinal changes and retinal cuff elevation. ${ }^{82,83}$ Post-mortem studies of macular holes have shown retinal degeneration suggesting the inability to support good vision. ${ }^{83,84}$ Paradoxically, clinical and surgical experience have demonstrated that some macular holes do resolve spontaneously or in response to surgery, with the return of excellent visual acuity. ${ }^{85-87}$ Clinical observations have led to the impression that the macular hole and cuff enlarge secondary to intrinsic retinal contraction and/or tangential traction from the vitreous cortex with or without premacular membranes. ${ }^{84}$ The observation of advancing visual loss despite no further apparent tissue loss led to the hypothesis that vision might stabilise or improve in some eyes if it were possible to relieve traction and reduce the cystic changes by surgically reattaching the cuff of retina surrounding the hole. Initial studies utilising vitrectomy techniques suggest that this can be achieved. ${ }^{87}$ However, the fact that vision only improves in about half of these cases suggests that surgery is not appropriate in all patients and that improved case selection is necessary prior to widespread promulgation of this surgical approach.

Impending Macular Holes. Macular holes are bilateral in 
Table I. Postulated mechanisms of macular hole formation.

\begin{tabular}{|c|c|c|c|c|}
\hline Type & Operculated & PVD & PMM & Mechanism/comments \\
\hline $\mathrm{O}$ & + & - & - & $\begin{array}{l}\text { Intravitreal fibres with traction on central macula cause operculated hole, } \\
\text { without PVD }\end{array}$ \\
\hline $\mathrm{OM}$ & + & - & + & $\begin{array}{l}\text { Premacular membrane and attached vitreous cortex with tangential traction } \\
\text { forces directed inwards towards the fovea (centripetal) tearing a hole about } \\
\text { fovea }\end{array}$ \\
\hline OP & + & + & - & $\begin{array}{l}\text { During PVD abnormal vitreo-macular adhesion about the fovea tears a hole } \\
\text { with an operculum attached to the premacular vitreous cortex }\end{array}$ \\
\hline OPM & + & + & + & $\begin{array}{l}\text { Two possible mechanisms: (a) Same as type OP, but PMM grows after PVD } \\
\text { and is unrelated. (b) PVD occurs innocuously but PMM grows after PVD } \\
\text { and tears a hole in perifoveal macula due to centripetal (towards the fovea) } \\
\text { forces including inward contraction of the PMM }\end{array}$ \\
\hline $\mathrm{P}$ & - & + & - & $\begin{array}{l}\text { Two possible mechanisms: (a) PVD not true but splits vitreous cortex } \\
\text { leaving posterior layer attached to macula (vitreoschisis). Outward (away } \\
\text { from the fovea) traction induces centrifugal forces opening a hole in the } \\
\text { central macula which widens with dome-like elevation of central macula. } \\
\text { (Surgery effective.) (b) PVD not complete but remains attached to macula } \\
\text { and exerts anteroposterior traction elevating a dome in the central macula, } \\
\text { opening hole centrally. (Surgery effective.) }\end{array}$ \\
\hline $\mathbf{M}$ & - & - & + & $\begin{array}{l}\text { PMM grows in absence of PVD causing centrifugal (outwards, away from } \\
\text { the fovea) traction opening a hole in the central macula. (Surgery effective.) }\end{array}$ \\
\hline
\end{tabular}

Key: PVD, posterior vitreous detachment; PMM, premacular membrane; O, operculated hole; OM, operculated hole with PMM; OP, operculated hole with PVD; OPM, operculated hole with PVD and PMM; P, non-operculated hole with PVD; M, non-operculated hole with PMM; +, present; -, absent.

approximately $10 \%$ of cases. Patients may be unaware of visual loss from a macular hole in the first eye. However, they will usually notice the slightest visual disturbance in the fellow eye. Patients with impending macular hole will usually complain of blurred central vision, metamorphopsia, or the appearance of a central grey area. Examination reveals decreased visual acuity (20/25 to 20/50) in most cases. Typically, biomicroscopy will reveal no posterior vitreous separation. Contact lens examination will show a foveal detachment with a loss of the foveal pit. ${ }^{81}$ In addition there is usually a deep yellow spot or yellow ring in the fovea. ${ }^{81}$ Occasionally fine radiating striae will be seen around the foveal lesion.

Some patients may experience spontaneous resolution of their symptoms. ${ }^{81,86}$ Examination of such patients will reveal visual improvements with subsidence of the yellow foveal lesion. Occasionally a pseudoperculum will be present and the fovea may become thinner. The pseudoperculum may be noticed by the patient as a small opacity moving in front of the visual axis. ${ }^{81}$ Presumably, in such patients, there is spontaneous separation of the vitreous cortex over the macula resulting in release of vitreous traction. Occasionally a fragment of internal limiting lamina or inner retina may be avulsed during this process resulting in lamellar macular hole with thinned fovea. In other instances the early lesion will progress to full-thickness macular hole resulting in further visual loss. Since vitreous traction appears to play a role in the progression of these early lesions, vitreous surgery with the removal of vitreous cortex and release of vitreous traction has been attempted. ${ }^{88,89}$ The value of vitrectomy in impending macular holes is currently being assessed by a prospective, multicentre, randomised clinical trial in the United States. ${ }^{90,91}$

\section{Vitreo-macular Traction Syndrome}

Another tractional disorder of the vitreo-macular interface is referred to as the vitreo-macular traction syndrome. ${ }^{34,92-94}$ Believed to be uncommon, although likely to be substantially under-recognised, this disease is characterised by partial PVD and vitreous traction on the macula. This can either result from superior PVD with persistent attachment at the macula or PVD everywhere except at the macula (Fig. 7). The finding that some individuals, especially in younger age groups, have usually strong attachment between the posterior vitreous cortex and macula and the peripapillary retina ${ }^{95}$ supports the concept that during PVD the vitreous can remain attached to the posterior pole and cause traction on the macula (Figs. 6 and 7). The area of residual vitreo-retinal attachment probably varies in extent between different individuals.

Clinically, the vitreo-macular traction syndrome causes gradual, progressive visual loss and metamorphopsia, with visual acuity usually at or below the $6 / 60$ level. ${ }^{96}$ Fluorescein angiography usually demonstrates leakage in a pattern reminiscent of cystoid macular oedema although the amount of leakage is typically less than would be expected for a given degree of visual loss, ${ }^{96}$ and a petalloid pattern is not routinely identified.

The natural history of this disease is variable and depends upon the status of the posterior vitreous cortex. Occasionally the posterior vitreous cortex spontaneously separates from the macula resulting in release of vitreous traction and visual improvement, ${ }^{34}$ similar to what has 

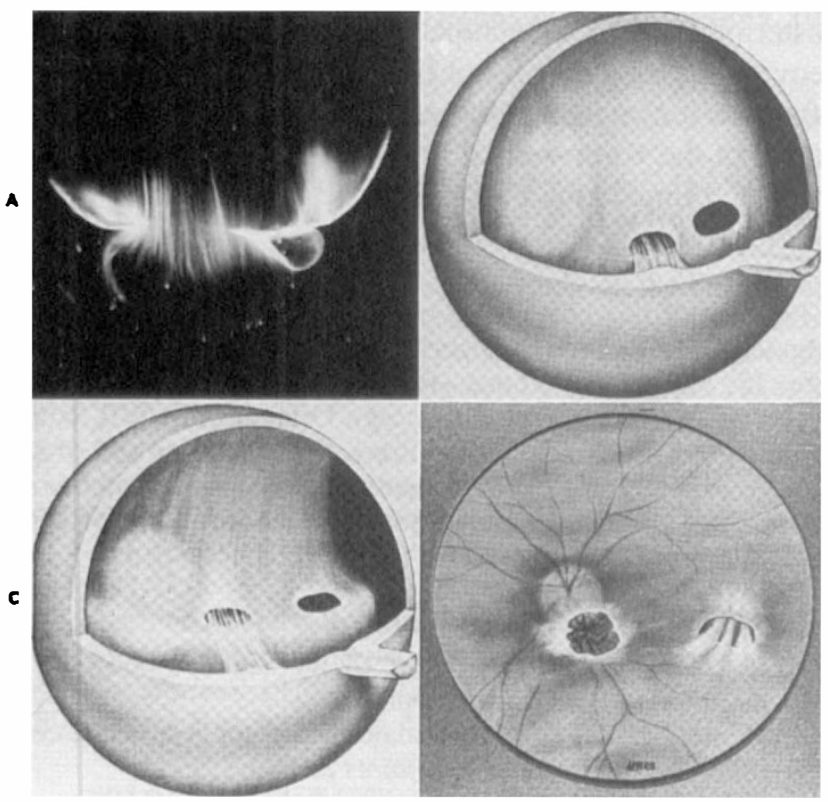

Fig. 7. Vitreo-macular traction. Vitreous can remain attached to the macula even in the presence of posterior vitreous detachment. In such cases, vitreous can extrude through the premacular vitreous cortex and fibres can insert into the macula. $B, C$ and $D$ are an artist's rendition of this phenomenon. $A$ demonstrates actual vitreous extrusion into the retrocortical space in a post-mortem human specimen. (Reprinted with permission from Sebag J: The Vitreous: Structure, Function, and Pathobiology. New York: Springer-Verlag, 1989, p. 134.)

been observed in some early macular holes. ${ }^{86}$ Vitreous surgery can be undertaken to release vitreous traction ${ }^{94,96}$ by dissecting the posterior vitreous cortex and peeling it from the retinal surface. Peripapillary vitreo-retinal attachment can be strong and resist peeling manoeuvres, often necessitating transection with the vitrectomy instrument. The visual results have been reviewed recently by Smiddy and co-workers ${ }^{96}$ who noted that approximately two thirds of their patients had visual improvement after surgery.

\section{Proliferative Disorders}

\section{Premacular Membranes}

Premacular membrane causing macular pucker, also known as premacular fibrosis or epiretinal membrane, is a well-known disease entity that can be either secondary or idiopathic. Secondary membranes are associated with a variety of retinal disorders, including retinal vascular diseases (branch retinal vein occlusion, central retinal vein occlusion), uveitis, trauma, or retinal detachment surgery.

Idiopathic premacular membranes usually afflict older patients and the condition is commonly unilateral. ${ }^{97}$ Traction exerted by the membrane causes leakage from the perifoveal capillaries, macular oedema detected on fluorescein angiography, and consequent visual loss. The presence and amount of leakage on fluorescein angioigraphy does not appear to correlate with visual results after vitrectomy ${ }^{98}$ although some studies have shown a negative correlation. ${ }^{99}$

Idiopathic premacular membranes have a wide range of severity. They can be quite subtle, causing minimal visual loss and manifesting only distortion of the retinal vasculature, or they can be quite substantial, obscuring the underlying retina. Most idiopathic premacular membranes are minimal and non-progressive, thus not requiring surgical intervention. In some patients, however, membranes can cause significant visual impairment and metamorphopsia, necessitating intervention. In such cases the goals of vitreous surgery are to peel the membrane off the mac-
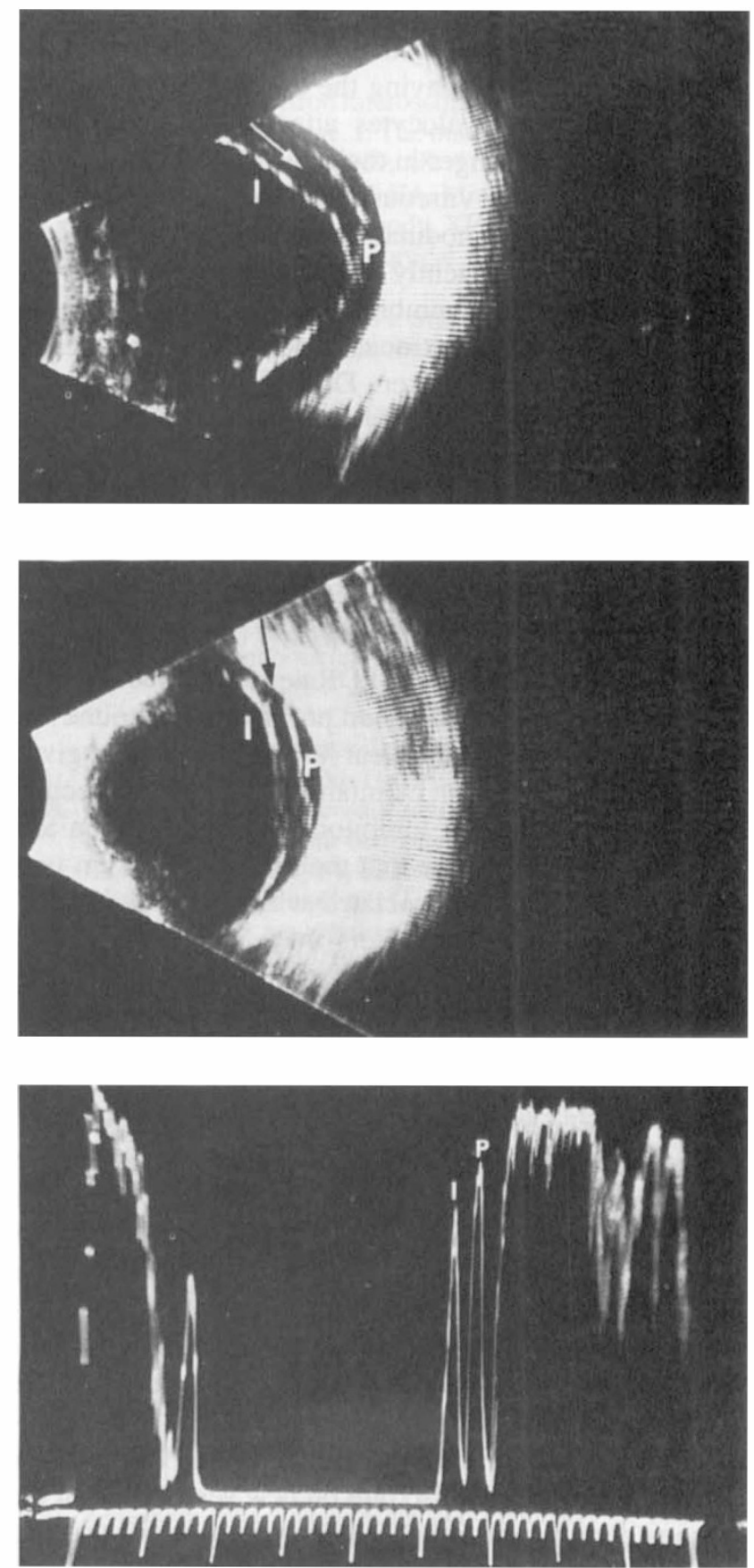

Fig. 8. Vitreoschisis. Splitting of the vitreous cortex (arrow) can occur and mimic posterior vitreous detachment. In diabetic patients blood can be present in the vitreoschisis cavity as demonstrated by B-scan ultrasonography. I, inner wall; $P$, posterior vitreous cortex. (Photograph courtesy of Dr Ronald Green, reprinted with permission from Green RL and Byrne SF: Diagnostic ophthalmic ultrasound. In: Ryan SJ, ed. Retina. St. Louis: CV Mosby, 1989. 
ula, relieving traction upon the retina and improving visual symptoms. ${ }^{97-101}$ Studies on excised tissue have demonstrated that both the number and types of cells found in these membranes vary considerably. Although most reports describe the presence of astrocytes and retinal pigment epithelial cells ${ }^{102-104}$ there are likely to be other cells that can appear similarly, such as macrophages and hyalocytes.

The subcategory of so-called hypocellular premacular membranes ${ }^{103}$ is very likely to result from PVD with a split in the vitreous cortex leaving the outermost layer of vitreous cortex with hyalocytes attached to the macula. These cells are no longer in their normal milieu since the previously overlying vitreous has detached forwards and no longer exerts any modulating effect(s) on these hyalocytes. ${ }^{105}$ They consequently can migrate or proliferate to form more extensive membranes. More likely, however, these cells contract the vitreous cortex attached to the ILL and induce macular pucker. Dissection of such membranes off the ILL is relatively easy since there are no cellular attachments to the retina-in contrast to membranes with a prominent astroglial component, where dissection is more difficult and often involves inadvertent excision of the ILL.

\section{Proliferative Diabetic Retinopathy (PDR)}

Studies ${ }^{106}$ have shown that in PDR new blood vessels form as a result of cell migration and proliferation into the vitreous cortex. It is not quite clear how this can occur, given the role of the vitreous in maintaining clarity of the ocular media via the action of inhibitors of cell migration and proliferation. ${ }^{105}$ It may be that the leakage of serum proteins into the vitreous associated with the breakdown of the blood-ocular barriers alters these inhibitory properties. Alternatively, enzyme-mediated cross-linking of vitreous collagen due to diabetes and hyperglycaemia-related non-enzymic glycation of collagen and other vitreous proteins ${ }^{107}$ could alter the extracellular matrix components at the vitreo-retinal interface and facilitate cell migration and proliferation in response to angiogenic stimuli. Once new vessels have grown into the posterior vitreous cortex, the aforementioned effects on vitreous collagen and the protein core of proteoglycans within the vitreous could cause liquefaction, and destabilisation of the vitreous with partial collapse, inducing traction upon these new vessel complexes. Splitting of the posterior vitreous cortex ('vitreoschisis') has been identified by ultrasound ${ }^{108}$ in $22 \%$ of patients with PDR (Fig. 8). This phenomenon can also pull on new vessels within the vitreous cortex and stimulate further neovascularisation. Subsequent vitreous haemorrhage and traction retinal detachment cause significant loss of vision in these patients. However, when new vessels grow in areas where the vitreous cortex is detached, the neovascular complexes appear as 'abortive outgrowths' ${ }^{109}$ and do not pose the same risks as those vessels growing onto and into the vitreous cortex. Indeed, part of the therapeutic effect of panretinal laser photocoagulation may be the induction of posterior vitreous detachment ${ }^{110}$ so that any subsequent neovascularisation will not have the vitreous cortex as a substrate for growth. Studies to characterise further the nature of the vitreo-retinal interface should lead to means by which innocuous PVD could be induced prior to the onset of neovascularisation.

Portions of this paper were originally published in Sebag J, Wendell R, DeBustros S: Disorders of the vitreo-macular interface. In: Margo CE, Mames RN, Hamed L, eds. Diagnostic Problems in Clinical Ophthalmology. Orlando, FL: WB Saunders (in press) and in Sebag J: Vitreous biochemistry and structure. In: Albert D and Jakobiec F, eds. Principles and Practice of Ophthalmology: The Harvard System. Orlando, FL: WB Saunders (in press).

\section{REFERENCES}

1. Duke-Elder WS: The nature of the vitreous body. $\mathrm{Br} J$ Ophthalmol 1930, 14 (Suppl): 6.

2. Demours F: Observations anatomiques sur la structure cellulaire du corps vitre. Memoires de Paris, 1741.

3. Zinn: Descriptio anatomica oculi humani. Goettingen, 1780.

4. Hannover A: Endeckung des Baues des Glaskorpers. Müller Arch 1845: 467-77.

5. Smith D: Structure of the adult human vitreous humour. Lancet 1868, ii: 365.

6. Von Gerlach H: Beiträge zur normalen Anatomie des menschliches Auges, 1880.

7. Bowman W: Observations on the structure of the vitreous humour. Dublin Q J Med Sci 1848, VI: 102.

8. Blix R: Studier ofver glaskroppen. Medicinsk Arch 1868: 14.

9. Retzius S: Om membrana limitans retinae interna. Norkdiskt Arch 1871, III(2): 1-34.

10. Virchow H: Die morphologische Natur des Glaskörpergeebes. Ber der 17. Ophthalmol Gesellsch Heidelberg, Klin Monatsbl Augenheilkd, 1885.

11. Szent-Gyorgi A: Untersuchungen über die Struktur des Glaskörpers des Menschen. Arch Mikrosc Anat 1917, 89: 324-86.

12. Redslob E: Le corps vitre. Masson et Cie, Paris, 1932: 174-8.

13. Gullstrand A: Die Nernspaltlampe in der ophthalmologischen Praxis. Klin Monatsbl Augenheilkd 1912, 50: 483-5.

14. Koeppe L: Clinical observations with the slit lamp. Arch Ophthalmol 1917, XC/XCVI: 232-49.

15. Baurmann G: Über die Beziehungen der ultramikroscopischen Glaskörperstruktur zu den Spaltlampen befunden. Albrecht von Graefes Arch Klin Exp Ophthalmol 1926, 117: 304 .

16. Goedbloed J: Studien am Glaskörper. I. Die Struktur des Glaskörpers. Albrecht von Graefes Arch Klin Exp Ophthalmol 1934 323-52.

17. Friedenwald JF and Stiehler RD: Structure of the vitreous. Arch Ophthalmol 1935, 14: 789-808.

18. Eisner G: Biomicroscopy of the Peripheral Fundus. Springer-Verlag, New York, 1973.

19. Worst JGF: Cisternal systems of the fully developed vitreous body in the young adult. Trans Ophthalmol Soc UK 1977, 97: 550-4.

20. Sebag J: Age-related changes in human vitreous structure. Graefes Arch Clin Exp Ophthalmol 1987, 225: 89-93.

21. Sebag J and Balazs EA: Pathogenesis of CME: anatomic consideration of vitreo-retinal adhesions. Surv Ophthalmol 1984, 28 (Suppl): 493-8.

22. Sebag $\mathrm{J}$ and Balazs EA: Human vitreous fibres and vit- 
reoretinal disease. Trans Ophthalmol Soc UK 1985, 104: $123-8$.

23. Sebag J and Balazs EA: Morphology and ultrastructure of human vitreous fibers. Invest Ophthalmol Vis Sci 1989, 30: 1867-71.

24. Sebag J: Ageing of the vitreous. Eye 1987, 1: 254-62.

25. Kishi S and Shimizu K: Posterior precortical vitreous pocket. Arch Ophthalmol 1990, 108: 979-82.

26. Gartner J: Electronmicroscopic study on the fibrillar network and fibrocyte-collagen interactions in the vitreous cortex at the ora serrata of human eyes with special regard to the role of disintegrating cells. Exp Eye Res 1986, 42: 21-33.

27. Hogan MJ: The vitreous: its structure in relation to the ciliary body and retina. Invest Ophthalmol 1963, 2: 418-45.

28. Gloor BP and Daicker BC: Pathology of the vitreo-retinal border structures. Trans Ophthalmol Soc UK 1975, 95: 387-90.

29. Gartner J: The fine structure of the vitreous base of the human eye and the pathogenesis of pars planitis. Am J Ophthalmol 1971, 71: 1317-27.

30. Balazs EA: Molecular morphology of the vitreous body. In: Smelser GK, ed. The Structure of the Eye. New York and London: Academic Press, 1961: 293-310.

31. Streeten BA: Disorders of the vitreous. In: Garner A andKlintworth GK, eds. Pathobiology of Ocular Disease: A Dynamic Approach. New York: Dekker, 1982: 1381-1419.

32. Theopold H and Faulborn J: Scanning electron microscopic aspects of the vitreous body. Mod Probl Ophthalmol 1979, 20: 92-5.

33. Streeten BA: Disorders of the vitreous. In: Garner A and Klintworth GK, eds. Pathobiology of Ocular Disease: A Dynamic Approach. New York: Dekker, 1982: 1381-1419.

34. Jaffe NS: Vitreous traction at the posterior pole of the fundus due to alterations in the vitreous posterior. Trans Am Acad Ophthalmol Otolaryngol 1967, 71: 642.

35. Reeser FH and Aaberg T: Vitreous humor. In: Records PE, ed. Physiology of the Human Eye and Visual System. Hagerstown: Harper \& Row, 1979: 1-31.

36. Hannover A: Endeckung des Baues des Glaskörpers. Müller Arch 1845: 467-77.

37. Schwalbe G: In: Engelmann W, ed. Von Graefe-Saemisch's Handbuch der gesamten Augenheilkunde, Vol I. Leipzig, 1874: 457.

38. Schwalbe G: Lehrbuch der Anatomie des Auges. Erlangen: E. Besold, 1887: 288.

39. Balazs EA: Acta XVIII Concilium Ophthalmologicum, Vol II. Brussels 1958: 1296.

40. Balazs EA, Toth LZ, Eckl EA, Mitchell AP: Studies on the structure of the vitreous body. XII. Cytological and histochemical studies on the cortical tissue layer. Exp Eye Res 1964, 3: 57-71.

41. Gloor BP: Cellular proliferation on the vitreous surface after photocoagulation. Graefes Arch Clin Exp Ophthalmol 1969, 178: 99-113.

42. Balazs EA: Molecular morphology of the vitreous body. In: Smelser GK, ed. The Structure of the Eye. New York and London: Academic Press, 1961: 293-310.

43. Bloom GD, Balazs EA: An electron microscope study of hyalocytes. Exp Eye Res 1965, 4: 249-55.

44. Hogan MJ, Alvarado JA, Weddel JE: Histology of the Human Eye: An Atlas and Textbook. Philadelphia: WB Saunders, 1971.

45. Saga T, Tagawa Y, Takeuchi T, et al.:Electron microscopic study of cells in vitreous of guinea pig. Jpn J Ophthalmol 1984, 28: 239-47.

46. Osterlin SE: The synthesis of hyaluronic acid in the vitreous. III. In vivo metabolism in the owl monkey. Exp Eye Res 1968, 7: 524-33.
47. Jacobson B: Identification of sialyl and galactosyl transferase activities in calf vitreous hyalocytes. Curr Eye Res 1984, 3: 1033-41.

48. Ayad S and Weiss JB: A new look at vitreous humour collagen. Biochem J 1984, 218: 835-40.

49. Newsome DA, Linsemayer TF, Trelsted RJ: Vitreous body collagen: evidence for a dual origin from the neural retina and hyalocytes. J Cell Biol 1976, 71: 59-67.

50. Hoffmann K, Baurwieg H, Riese K: Über Gehalt und Verteilung nieder und hoch molekulärer Substanzen in Glaskörper. II. Hoch molekuläre Substanzen (LDH, MDH, GOT). Graefes Arch Clin Exp Ophthalmol 1974, 191: 231-8.

51. Teng CC: An electron microscopic study of cells in the vitreous of the rabbit eye. I. The macrophage. Eye, Ear, Nose and Throat Monthly 1969, 48: 91-104.

52. Balazs EA, Toth LZ, Eckl EA, Mitchell AP: Studies on the structure of the vitreous body. XII. Cytological and histochemical studies on the cortical tissue layer. Exp Eye Res 1964, 3: 57-71.

53. Szirmai JA and Balazs EA: Studies on the structure of the vitreous body. III. Cells in the cortical layer. Arch Ophthalmol 1958, 59: 34-40.

54. Grabner G, Baltz G, Forster O: Macrophage-like properties of human hyalocytes. Invest Ophthalmol Vis Sci 1980, 19: $333-40$.

55. Forrester JV, Balazs EA: Inhibition of phagocytosis by high molecular weight hyaluronate. Immunology 1980, 40: 435-46.

56. Sebag J, Balazs EA, Eakins KE, Kulkarni P: The effect of Na-hyaluronate on prostaglandin synthesis and phagocytosis by mononuclear phagocytes. Invest Ophthalmol Vis Sci (ARVO) 1981, 20: 33.

57. Balazs EA, Toth LZ, Ozanics V: Cytological studies on the developing vitreous as related to the hyaloid vessel system. Graefes Arch Clin Exp Ophthalmol 1980, 213: 71-85.

58. Bleckmann H: Glycosaminoglycan metabolism of cultured fibroblasts from bovine vitreous. Graefes Arch Clin Exp Ophthalmol 1984, 222: 90-4.

59. Birk DE and Zycbard EI: Collagen fibrillogenesis in situ: fibril segments are intermediates in matrix assembly. Proc Natl Acad Sci USA 1989, 86: 4549-53.

60. Fine BS and Tousimis AJ: The structure of the vitreous body and the suspensory ligaments of the lens. Arch Ophthalmol 1961, 65: 95-110, 119-34.

61. Gartner J: Vitreous electron microscopic studies on the fine structure of the normal and pathologically changed vitreoretinal limiting membrane. Surv Ophthalmol 1964, 9: $291-4$

62. Matsumoto B, Blanks JC, Ryan SJ: Topographic variation in the rabbit and primate internal limiting membrane. Invest Ophthalmol Vis Sci 1984, 25: 71.

63. Anderson DR: Ultrastructure of the optic nerve head. Arch Ophthalmol 1970, 83: 63-73.

64. Foos RY: Vitreoretinal juncture: topographical variations. Invest Ophthalmol 1972, 11: 801-8.

65. Uga A: Some structural features of the retinal Müllerian cells in the juxtaoptic nerve region. Exp Eye Res 1974, 19: 105-15.

66. Kefalides NA: The biology and chemistry of basement membranes. In: Kefalides NA, ed. Proceedings of the First International Symposium on the Biology and Chemistry of Basement Membranes. New York: Academic Press, 1978: 215-28.

67. Goodnight R, Nagy AR, Ryan SJ: Differential distribution of laminin in rabbit and monkey retinas. Invest Ophthalmol Vis Sci (ARVO) 1988, 29: 203.

68. Jerdan JA, Pepose JS, Michels RG, et al.: Proliferative vitreoretinopathy membranes: an immunohistochemical study. Ophthalmology 1989, 96: 801-10. 
69. Hiscott $\mathrm{P}$, Waller HA, Grierson I, et al.: Local production of fibronectin by ectopic human retinal cells. Cell Tissue Res 1992, 267: 185-92.

70. Kohno T, Sorgnte N, Ishibashi T, et al.: Immunofluorescent studies of fibronectin and laminin in the human eye. Invest Ophthalmol Vis Sci 1987, 28: 500-14.

71. Russel SR, Shepherd JD, Hageman GS: Distribution of glycoconjugates in the human retinal internal limiting membrane. Invest Ophthalmol Vis Sci 1991, 32: 1986-95.

72. Heergaard S and Jensen OA, Prause JU: Structure of the vitread face of the monkey optic disc (Macacca mulatta): SEM on frozen resin-cracked optic nerve heads supplemented by TEM and immunohistochemistry. Graefes Arch Clin Exp Ophthalmol 1988, 226: 377-83.

73. Balazs EA: Functional anatomy of the vitreous. In: Duane TD and Jaeger EA, eds. Biomedical Foundations of Ophthalmology, Vol 1. Philadelphia: Harper \& Row, 1982: 6-12.

74. Zimmerman LE and Straatsma BR: Anatomic relationships of the retina to the vitreous body and to the pigment epithelium. In: Schepens CL, ed. Importance of the Vitreous Body in Retina Surgery with Special Emphasis on Regeneration. St. Louis: CV Mosby, 1960: 15-28.

75. Kuwabara $T$ and Cogan DG: Studies of retinal vascular patterns. I. Normal architecture. Arch Ophthalmol 1960, 64: 904-11.

76. Pedler C: The inner limiting membrane of the retina. $B r J$ Ophthalmol 1961, 45: 423.

77. Wolter JR: Pores in the internal limiting membrane of the human retina. Acta Ophthalmol 1964, 42: 971-4.

78. Mutlu F and Leopold IH: Structure of the human retinal vascular system. Arch Ophthalmol 1964, 71: 93.

79. Morgan CM and Schatz H: Involutional macular thinning: a pre-macular hole condition. Ophthalmology 1986, 93: 153-61.

80. Schepens CL: Clinical aspects of pathologic changes in the vitreous body. Am J Ophthalmol 1984, 38: 8.

81. Gass JDM: Idiopathic senile macular hole: its early stages and pathogenesis. Arch Ophthalmol 1988, 106: 629-39.

82. Aaberg TM, Blair JB, Gass JDM: Macular holes. Am J Ophthalmol 1970, 64: 555-62.

83. Frangieh GT, Green WR, Engel HM: A histopathologic study of macular cysts and holes. Retina 1981, 1: 311-36.

84. Guyer DR, Green WR, de Bustros, S, et al.: Histopathologic features of idiopathic macular holes and cysts. Ophthalmology 1990, 97: 1045-51.

85. Bidwell AE, Jampol LM, Goldberg MF: Macular holes and excellent visual acuity. Arch Ophthalmol 1988, 106: 1350-1.

86. Wizni RA: Reversibility of early stages of idiopathic macular holes. Am J Ophthalmol 1989, 107: 241.

87. Kelly NE and Wendell RT: Vitreous surgery for idiopathic macular holes. Arch Ophthalmol 1991, 109: 654-9.

88. Smiddy WE, Michels RG, Glaser BM: Vitrectomy for impending idiopathic macular holes. Am J Ophthalmol 1988, 105: 371-6.

89. Jost BF, Hutton WL, Fuller DG, et al.: Vitrectomy in eyes at risk for macular hole formation. Ophthalmology 1990, 97: 843-7.

90. de Bustros S: Early stages of macular holes: to treat or not to treat. Arch Ophthalmol 1990, 108: 1085-6.

91. de Bustros S: Vitrectomy for prevention of macular hole: study [letter]. Arch Ophthalmol 1991, 109: 1057.
92. Schepens CL: Fundus changes caused by alterations of the vitreous body. Am J Ophthalmol 1955, 39: 631-3.

93. Reese AB, Jones IS, Cooper WC: Vitreomacular traction syndrome confirmed histologically. Am J Ophthalmol 1970, 69: 975-90.

94. Margherio RR, Trese MT, Margherio AR, et al.: Surgical management of vitreomacular traction syndromes. Ophthalmology 1989, 96: 1437-42.

95. Sebag J: Age-related differences in the human vitreoretinal interface. Arch Ophthalmol 1991, 109: 960-71.

96. Smiddy WE, Michels RG, Glaser BM, et al.: Vitrectomy for macular traction caused by incomplete vitreous separation. Arch Ophthalmol 1988, 197: 624-8.

97. Rice TA, de Bustros S, Michels RG, et al.: Prognostic factors in vitrectomy for epiretinal membranes of the macula. Ophthalmology 1986, 93: 602-10.

98. Pesin SR, Olk RJ, Grand MG, et al.: Vitrectomy for premacular fibroplasia: prognostic factors, long-term follow-up, and time course of visual improvement. Ophthalmology 1991, 98: 1109-14.

99. Poliner LS, Olk RJ, Grand MG, et al.: Predictive variables in surgical management of premacular fibroplasia. Arch Ophthalmol 1988, 106: 761-5.

100. de Bustros S, Thompson JT, Michels RG, et al.: Vitrectomy for idiopathic epiretinal membranes causing macular pucker. Br J Ophthalmol 1988, 72: 692-5.

101. Margherio RR, Cox MS, Trese MT, et al.: Removal of epimacular membranes. Ophthalmology 1985, 92: 1075-83.

102. Michels RG: A clinical and histopathologic study of epiretinal membranes affecting the macula and removed by vitreous surgery. Trans Am Ophthalmol Soc 1982, 80: $580-656$.

103. Clarkson JG, Green WR, Massof D: A histopathologic review of 168 cases of preretinal membranes. Am J Ophthalmol 1977, 84: 1-17.

104. Smiddy WE, Maguire AM, Green WR, et al.: Idiopathic epiretinal membranes: ultrastructural characteristics and clinicopathologic correlation. Ophthalmology 1989, 96: 811-20.

105. Sebag J: The Vitreous: Structure, Function and Pathobiology. New York: Springer-Verlag, 1989: 60-1.

106. Faulborn $\mathrm{J}$ and Bowald $\mathrm{S}$ : Microproliferations in proliferative diabetic retinopathy and their relation to the vitreous: corresponding light and electron microscopic studies. Graefes Arch Clin Exp Ophthalmol 1985, 223: 130-8.

107. Sebag J, Buckingham B, Charles MA, Reiser KA: Biochemical changes in vitreous from humans with proliferative diabetic retinopathy. Arch Ophthalmol 1992 (in press).

108. Chu TG, Green RL, Cano MR, et al.: Schisis of the posterior vitreous cortex: an ultrasonographic finding in diabetic retinopathy. Invest Ophthalmol Vis Sci (ARVO) 1991, 32: 1769.

109. Wong HC, Schmiks K, McLeod D: Abortive neovascular outgrowths discovered during vitrectomy for diabetic vitreous haemorrhage. Graefes Arch Clin Exp Ophthalmol 1989, 227: 237-40.

110. Sebag J, Buzney SM, Belyea DA, et al.: Posterior vitreous detachment following panretinal laser photocoagulation. Grafes Arch Clin Exp Ophthalmol 1990, 228: 5-8. 